\title{
Population surveillance for microcephaly
}

\author{
(c) $(\mathbb{Q} \Theta$ OPEN ACCESS \\ Surveillance is an essential part of the response to Zika and must be improved
}

\author{
Russell S Kirby professor \\ Department of Community and Family Health, College of Public Health, University of South Florida, Tampa, FL, USA
}

Emerging infectious diseases have challenged existing public health infrastructure and validated its necessity on the front lines of defense. The 2014-15 epidemic of Ebola virus in west Africa occurred in countries with limited capacity of healthcare facilities and providers and almost no population based health surveillance systems. The Zika virus outbreaks have also previously occurred mainly in areas with fewer resources but with a difference. The virus has been shown to be highly teratogenic. ${ }^{1}$ Even in regions with well resourced perinatal surveillance programs, the nature and severity of the birth defects associated with exposure to Zika virus in utero challenge their infrastructure. While we wait for a comprehensive understanding of the phenotypic expression of exposure, considerable activity has focused on the baseline prevalence of central nervous system anomalies, particularly microcephaly. A linked paper by Morris and colleagues (doi:10.1136/bmj. i4721) makes clear just how difficult it can be to ascertain accurate, reliable, and reproducible data on the baseline prevalence of these congenital defects within existing surveillance systems. ${ }^{2}$ The authors conclude that shortcomings in surveillance coupled with the rarity of microcephaly mean that changes in prevalence potentially due to the Zika virus could be missed.

Microcephaly is not a birth defect per se but rather a description of head size in an infant or child in relation to growth charts adjusted for gestational or chronological age, sex, and race/ethnicity. Clinical diagnoses might not reflect the case definitions applied by birth defects registries. Also, although microcephaly can be diagnosed at birth, during infancy, or at a later time, most birth defects surveillance programs monitor diagnoses in the first year of life. Cases diagnosed after birth might be congenital in origin, or have an acquired aetiology, and developmental concerns can trigger the diagnosis. Morris and colleagues examined the prevalence of microcephaly in 24 regions of Europe during 2003-12. ${ }^{2}$ Many of the participating EUROCAT registries are small, with only three covering more than 50000 annual births, while seven cover fewer than 10000 . The point estimates for microcephaly vary by an order of magnitude from 0.4 to 4.3 per 10000 births, with an overall estimate of 1.53 (95\% confidence interval 1.16 to 1.96 ) per 10
000 births. The EUROCAT study used a conservative definition of microcephaly (a reduction in the size of the brain, with a skull circumference more than 3 SD below the mean for sex, age, and ethnic origin). In North America, the diagnosis of microcephaly is often based on the third centile for head circumference, or $2 \mathrm{SD}$ as one of the clinical features. ${ }^{3}$

The EUROCAT study reports a relatively low background prevalence of microcephaly in Europe. ${ }^{2}$ This could be partly due to the conservative case definition used, and the exclusion of cases with known genetic disorders, including chromosomal abnormalities, syndromes, and microdeletions. Yet there was considerable variability across the 24 participating registries. The observed differences could be due to random variability, given the small populations involved. Other possibilities include heterogeneity in diagnostic criteria or their application by clinicians, variation in availability of prenatal diagnosis, rates of elective termination, methods of ascertainment in the birth defects registry, and the registry's ability to capture cases of infants who received a diagnosis after the initial stay in hospital after delivery or outside hospital care settings. Ironically, the National Birth Defects Prevention Network (NBDPN) in the US made the decision to discontinue annual reporting of microcephaly by state beginning with $2007-11$ because of extreme variability in state level prevalence reports, and microcephaly was not included among the conditions in the most recent report of US national prevalence estimates. ${ }^{45} \mathrm{~A}$ forthcoming report evaluating the prevalence of microcephaly in the US found a pooled prevalence of 8.8 per 10000 live births, with variation by whether case finding used passive or active ascertainment as well as demographic characteristics and perinatal outcomes, ${ }^{6}$ demonstrating that shortcomings in surveillance are not confined to Europe.

The first cluster of microcephaly cases in Brazil was identified by astute clinicians in 2015, and tentatively linked to an outbreak of the Zika virus beginning several months earlier. ${ }^{7}$ While a nationwide Brazilian reporting system based on birth registration suggested a fourfold increase in cases of microcephaly, no comprehensive birth defects registry was operating in northeastern Brazil. More recent estimates for prevalence of 
microcephaly in Brazil should be interpreted within the context of improved diagnosis and ascertainment. ${ }^{89}$

While Zika virus is an unlikely threat in much of Europe, the challenges for surveillance of birth defects should be addressed now to strengthen the quality and effectiveness of this essential public health function. Although microcephaly is a marker for a pregnancy potentially exposed to Zika virus, affected women might have no symptoms, and infants might present with other abnormalities of the central nervous system. Zika virus can affect brain development long after birth, with some exposed infants receiving the diagnosis of microcephaly in early childhood. Few birth defects registries follow cohorts beyond the first year after birth. While birth defects registries perform a vital population health function, registers of pregnancies affected by Zika virus with longitudinal follow-up of both mother and child must be established urgently to fully understand the natural course of the Zika syndrome and its impact on child growth and development.

Competing interests: I have read and understood the BMJ policy on declaration of interests and declare the following: none.

Provenance and peer review: Commissioned; not peer reviewed.

1 Rasmussen SA, Jamieson DJ, Honein MA, Petersen LR. Zika Virus and Birth Defects--Reviewing the Evidence for Causality. N Engl J Med 2016;374:1981-7. doi:10. 1056/NEJMsr1604338 pmid:27074377.

2 Morris J, Rankin J, Garne E, et al. Prevalence of microcephaly in Europe: population based study. BMJ 2016;354:14721.
3 Ashwal S, Michelson D, Plawner L, Dobyns WB. Quality Standards Subcommittee of the American Academy of Neurology and the Practice Committee of the Child Neurology Society. Practice parameter: Evaluation of the child with microcephaly (an evidence-based review): report of the Quality Standards Subcommittee of the American Academy of Neurology and the Practice Committee of the Child Neurology Society. Neurology 2009;73:887-97. doi:10.1212/WNL.0b013e3181b783f7 pmid:19752457.

4 Mai CT, Kucik JE, Isenburg J, et al. National Birth Defects Prevention Network. Selected birth defects data from population-based birth defects surveillance programs in the United States, 2006 to 2010: featuring trisomy conditions. Birth Defects Res A Clin Mol Teratol 2013;97:709-25. doi:10.1002/bdra.23198 pmid:24265125.

5 Parker SE, Mai CT, Canfield MA, et al. National Birth Defects Prevention Network. Updated National Birth Prevalence estimates for selected birth defects in the United States, 2004-2006. Birth Defects Res A Clin Mol Teratol 2010;88:1008-16. doi:10.1002/bdra. 20735 pmid:20878909.

6 Cragan JD, Isenburg JL, Parker SE, et al. Population-based microcephaly surveillance in the United States, 2009-2013: An analysis of potential sources of variation. Birth Defects Res A Clin Mol Teratol 2016; [forthcoming].

7 Schuler-Faccini L, Ribeiro EM, Feitosa IM, et al; Brazilian Medical Genetics Society-Zika Embryopathy Task Force. Possible association between Zika virus infection and microcephaly—Brazil, 2015. Morb Mortal Wkly Rep 2016;65:59-62.

8 Barcellos C, Xavier DR, Pavão A, et al. Increased hospitalizations for neuropathies in Brazil as indicators of Zika virus infection, according to health information system data, Brazil. Emerg Infect Dis. 2016 Nov [date cited]. http://dx.doi.org/10.3201/eid2211.160901

9 Kleber de Oliveira W, Cortez-Escalante J, De Oliveira WT, et al. Increase in Reported Prevalence of Microcephaly in Infants Born to Women Living in Areas with Confirmed Zika Virus Transmission During the First Trimester of Pregnancy - Brazil 2015. MMWR Morb Mortal Wkly Rep 2016;65:242-7. doi:10.15585/mmwr.mm6509e2. pmid:26963593.

Published by the BMJ Publishing Group Limited. For permission to use (where not already granted under a licence) please go to http://group.bmj.com/group/rights-licensing/ permissions

This is an Open Access article distributed in accordance with the Creative Commons Attribution Non Commercial (CC BY-NC 3.0) license, which permits others to distribute, remix, adapt, build upon this work non-commercially, and license their derivative works on different terms, provided the original work is properly cited and the use is non-commercial. See: http://creativecommons.org/licenses/by-nc/3.0/. 